\title{
Infection and propagation of lymphocystis virus isolated from the cultured flounder Paralichthys olivaceus in grass carp cell lines
}

\author{
Qi-Ya Zhang, Hong-Mei Ruan, Zhen-Qiu Li, Xiu-Ping Yuan, Jian-Fang Gui* \\ State Key Laboratory of Freshwater Ecology and Biotechnology, Wuhan Center for Developmental Biology, \\ Institute of Hydrobiology, Chinese Academy of Sciences, Wuhan 430072, PR China
}

\begin{abstract}
The causative agent of lymphocystis disease that frequently occurs in cultured flounder Paralichthys olivaceus in China is lymphocystis virus (LV). In this study, 13 fish cell lines were tested for their susceptibility to LV. Of these, 2 cell lines derived from the freshwater grass carp Ctenopharyngodon idellus proved susceptible to the LV, and 1 cell line, GCO (grass carp ovary), was therefore used to replicate and propagate the virus. An obvious cytopathic effect (CPE) was first observed in cell monolayers at $1 \mathrm{~d}$ post-inoculation, and at $3 \mathrm{~d}$ this had extended to about $75 \%$ of the cell monolayer. However, no further CPE extension was observed after 4 d. Cytopathic characteristics induced by the LV were detected by Giemsa staining and fluorescence microscopic observation with Hoechst 33258 staining. The propagated virus particles were also observed by electron microscopy. Ultrastructure analysis revealed several distinct cellular changes, such as chromatin compaction and margination, vesicle formation, cell-surface convolution, nuclear fragmentation and the occurrence of characteristic 'blebs' and cell fusion. This study provides a detailed report of LV infection and propagation in a freshwater fish cell line, and presents direct electron microscopy evidence for propagation of the virus in infected cells. A possible process by which the CPEs are controlled is suggested.
\end{abstract}

KEY WORDS: Lymphocystis virus $\cdot \mathrm{LV} \cdot$ Iridovirus $\cdot$ Viral disease $\cdot$ Freshwater fish $\cdot$ Cell line $\cdot$ Apoptosis

\section{INDRODUCTION}

Lymphocystis has recently been reported to occur frequently in cultured flounder Paralichthys olivaceus in China, and the causative agent has been identified as a lymphocystis virus, LV (Sun et al. 2000, Xu et al. 2000), that has been extensively described worldwide (Tidona \& Darai 1999). Lymphocystis disease was diagnosed early in 1874 , but the viral agent was not determined by direct electron microscopic observations until 1962 (Walker 1962). LV is an iridovirus (Flugel et al. 1982, Wolf 1988: p 268-291), and a series of studies, including morphological and ultrastructural descriptions (Zwillenberg \& Wolf 1968, Berthiaume et al. 1984, Samalecos 1986, Heppell \& Berthiaume 1992), molecular characterization and genome sequence identifica- tion (Flugel et al. 1982, Darai et al. 1983, Schnitzler \& Darai 1993, Tidona \& Darai 1997), have been carried out. The complete genomic DNA sequence of LV-1 (isolated in Germany) has been determined to be $102653 \mathrm{bp}$, and to contain 110 largely non-overlapping putative viral genes (Tidona \& Darai 1997).

Although great advances have been made in LV studies, the molecular mechanism underlying LV infection, replication and pathogenesis is not clearly known. The major obstacle to progress is the lack of an efficient cell-culture system for propagation of this virus (Tidona \& Darai 1999). In the past, many attempts have been made to propagate LV in vitro, but with limited success (Tidona \& Darai 1999). For example, Wolf et al. (1966) successfully assayed and quantified an LV strain by $\mathrm{TCID}_{50}$ and $\mathrm{ID}_{50}$ methods 
using the bluegill cell line BF-2. However, the titer yielded at 21 to $28 \mathrm{~d}$ post-infection was usually very low, and a complete replication of the virus has not been achieved for this cell line (Walker \& Hill 1980). Recently, Perez-Prieto et al. (1999) evaluated the susceptibility of a new continuous cell line, SAF-1, derived from the fins of the gilt-head seabream Sparus aurata L., to several viruses, including LV. A cytopathic effect (CPE) was first recorded at $3 \mathrm{~d}$ postinoculation, but only $25 \%$ of the cells were affected, and only $50 \%$ of the cell monolayer displayed by CPE at $6 \mathrm{~d}$ post-inoculation. Currently, much interest is being focused on the de-velopment of a susceptible cell-culture system for LV diagnosis, isolation, propagation and pathogenesis.

In recent years, more than 20 fish cell lines, derived from marine and freshwater fishes, have been cultured and maintained in our laboratory for the purpose of detecting and propagating specific virus pathogens (Zhang et al. 1999, 2000, Zhang 2002). In this study, we evaluated 13 fish cell lines for their susceptibility to the LV strain isolated from cultured flounder Paralichthys olivaceus in Qindao, China (Sun et al. 2000), and found 2 cell lines, GCO (grass carp ovary) and GCK (grass carp kidney) derived from the freshwater grass carp Ctenopharyngodon idellus, that are susceptible to the LV. We therefore used 1 cell line (GCO) to replicate and propagate the virus.

\section{MATERIALS AND METHODS}

Preparation of $\mathbf{L V}$ isolate. Lymphocystis tissues were sampled from the tumor-like dermal lesions of diseased cultured flounder in Qindao, Shandon Province, China (kindly provided by Professor X. Q. Sun). The tissues were homogenized in phosphate-buffered saline (PBS) containing antibiotics (penicillin, 100 I.U. $\mathrm{ml}^{-1}$; streptomycin, $100 \mu \mathrm{g} \mathrm{ml}^{-1}$ ). Extracts were stored overnight at $-20^{\circ} \mathrm{C}$, thawed, clarified by low-speed centrifugation, and the resulting supernatants containing LV were filtrated and used to infect cell lines or stored at -80 or $-20^{\circ} \mathrm{C}$.

Cell lines. For viral susceptibility tests (Zhang 1997), we used a total of 13 cell lines (see Table 1) including 10 established fish cell lines: GCK (grass carp kidney; Zuo et al. 1986), FHM (fathead minnow; Gravell \& Malsberger 1965), CAR (Carassius auratus blastula embryos; Wolf 1988; p 461), EPC (epithelioma papulosum cyprini; Fijan et al. 1983), EG (eel gonad; Chen \& Xie 1995), CHSE (chinook salmon embryo; Wolf 1988; p 461), RL (rainbow trout liver; Ahne 1985), RTG (rainbow trout gonad; Wolf 1988; p 461), CCO (channel catfish ovary; Bowser \& Plumb 1980) and PG (pike gonad; Ahne 1978); and 3 new fish cell lines, i.e. GCO (grass carp ovary; unpubl.), GCH (gibel carp heart; unpubl.) and SCE (silver carp embryo; Li \& Zhang 2000). The cells were grown in Tissue Culture 199 medium supplemented with $10 \%$ fetal bovine serum and antibiotics (100 I.U. penicillin $\mathrm{ml}^{-1} ; 100 \mu \mathrm{g}$ streptomycin $\mathrm{ml}^{-1}$ ). Culture temperature was $25^{\circ} \mathrm{C}$ unless otherwise stated.

Cell infection and virus propagation. The thawed LV isolates were inoculated separately onto confluent cell monolayers in 96-well plates as previously described (Zhang et al. 1996, 2000). The cytopathic effect (CPE) was observed by light microscopy.

Staining with Giemsa and Hoechst 33258. The infected and uninfected cells cultured on glass slides were fixed with 30 to $100 \%$ ethanol and stained with Giemsa; slides were examined under a light microscope. For Hoechst 33258 staining, cultures on glass slides were fixed with $4 \%$ formaldehyde in PBS, then rinsed twice (5 min each time), and stained with $5 \mu \mathrm{g}$

Table 1. Susceptibility to the LV of 13 fish cell lines.,,$++++++: \sim 25,50$ and $75 \%$ cells, respectively, displayed cytopathic effects $(\mathrm{CPE}) ;-$, no CPE observed

\begin{tabular}{|c|c|c|c|c|c|c|c|c|}
\hline \multirow{2}{*}{\multicolumn{2}{|c|}{ Cell line }} & \multicolumn{7}{|c|}{ CPE (time post-inoculation) } \\
\hline & & \multirow{2}{*}{$\frac{1 \mathrm{~d}}{-}$} & \multirow{2}{*}{$\frac{2 \mathrm{~d}}{+}$} & \multirow{2}{*}{$\frac{3 \mathrm{~d}}{++}$} & \multirow{2}{*}{$\frac{4 \mathrm{~d}}{++}$} & \multirow{2}{*}{$\frac{6 \mathrm{~d}}{++}$} & \multirow{2}{*}{$\frac{12 \mathrm{~d}}{++}$} & \multirow{2}{*}{$\begin{array}{r}18 \mathrm{~d} \\
++\end{array}$} \\
\hline GCK & (grass carp kidney) & & & & & & & \\
\hline FHM & (fathead minnow) & - & - & - & - & - & - & - \\
\hline CAR & (goldfish fin) & - & - & - & - & - & - & - \\
\hline EPC & (Epithelioma papulosum cyprini) & - & - & - & - & - & - & - \\
\hline EG & (eel gonad) & - & - & - & - & - & - & - \\
\hline CHSE & (chinook salmon embryo) & - & - & - & - & - & - & - \\
\hline RL & (rainbow trout liver) & - & - & - & - & - & - & - \\
\hline RTG & (rainbow trout gonad) & - & - & - & - & - & - & - \\
\hline $\mathrm{CCO}$ & (channel catfish ovary) & - & - & - & - & - & - & - \\
\hline PG & (pike gonad) & - & - & - & - & - & - & - \\
\hline GCO & (grass carp ovaries) & + & ++ & +++ & +++ & +++ & +++ & +++ \\
\hline $\mathrm{GCH}$ & (gibel carp heart) & - & - & - & - & - & - & - \\
\hline SCE & (silver carp embryos) & - & - & - & - & - & - & - \\
\hline
\end{tabular}


$\mathrm{ml}^{-1}$ Hoechst 33258 for $15 \mathrm{~min}$. The slides were rinsed twice (5 min each time) with PBS, and then mounted with $50 \mathrm{mMol} \mathrm{l}^{-1} \mathrm{Na}_{2} \mathrm{HPO}_{4}$ and $50 \%$ glycerol. The Hoechst 33258-stained slides were observed under a fluorescence microscope.

Transmission electron microscope observations. At Day 3 post-inoculation (CPE had extended to about $75 \%$ of the cell monolayer), the infected GCO cells were fixed with $2 \%$ glutaraldehyde, post-fixed in osmium tetroxide $\left(\mathrm{OsO}_{4}\right)$, dehydrated and embedded in Epon-812. Ultrathin sections were cut and stained with $2 \%$ uranyl acetate and lead citrate, and examined under a JEM-1230 electron microscope.

\section{RESULTS}

\section{Susceptibility of two grass carp cell lines to $\mathrm{LV}$}

Of the 13 fish cell lines examined, CPE were observed in only 2 grass carp cell lines, GCO and GCK (Table 1). In GCO cells, obvious CPE was first observed in cell monolayers at $1 \mathrm{~d}$ postinoculation, and had extended to about $75 \%$ of the cell monolayer at $3 \mathrm{~d}$ postinoculation (Fig. 1). In GCK cells, CPE was not recorded until $2 \mathrm{~d}$ post-inoculation, and the frequency of the affected cells was lower than with the GCO cells. However, no further CPE extension was observed after $4 \mathrm{~d}$ postinoculation for either cell line. These results indicated that the GCO and GCK cell lines were susceptible to the LV, and therefore the GCO cell line was used to propagate the virus. In a series of infection experiments, LV infection and propagation were performed for 8 passages in the GCO cell line.

\section{Light-microscope characteristics of cytopathic effects}

Cytopathic characteristics induced by the LV in GCO cells differed from those described previously for other aquatic animal viruses (Zhang et al. 1999, 2000, 2001). The infected cells showed increased microscopic refractivity and contraction. Some syncretic cell patches appeared on the monolayers, and some contracted cells were suspended in the media.

Giemsa staining revealed cell aggregation and fusion in the infected monolayers. A large number of cells aggregated in patches in affected areas, and these stained deeper red (Fig. 2A,B).
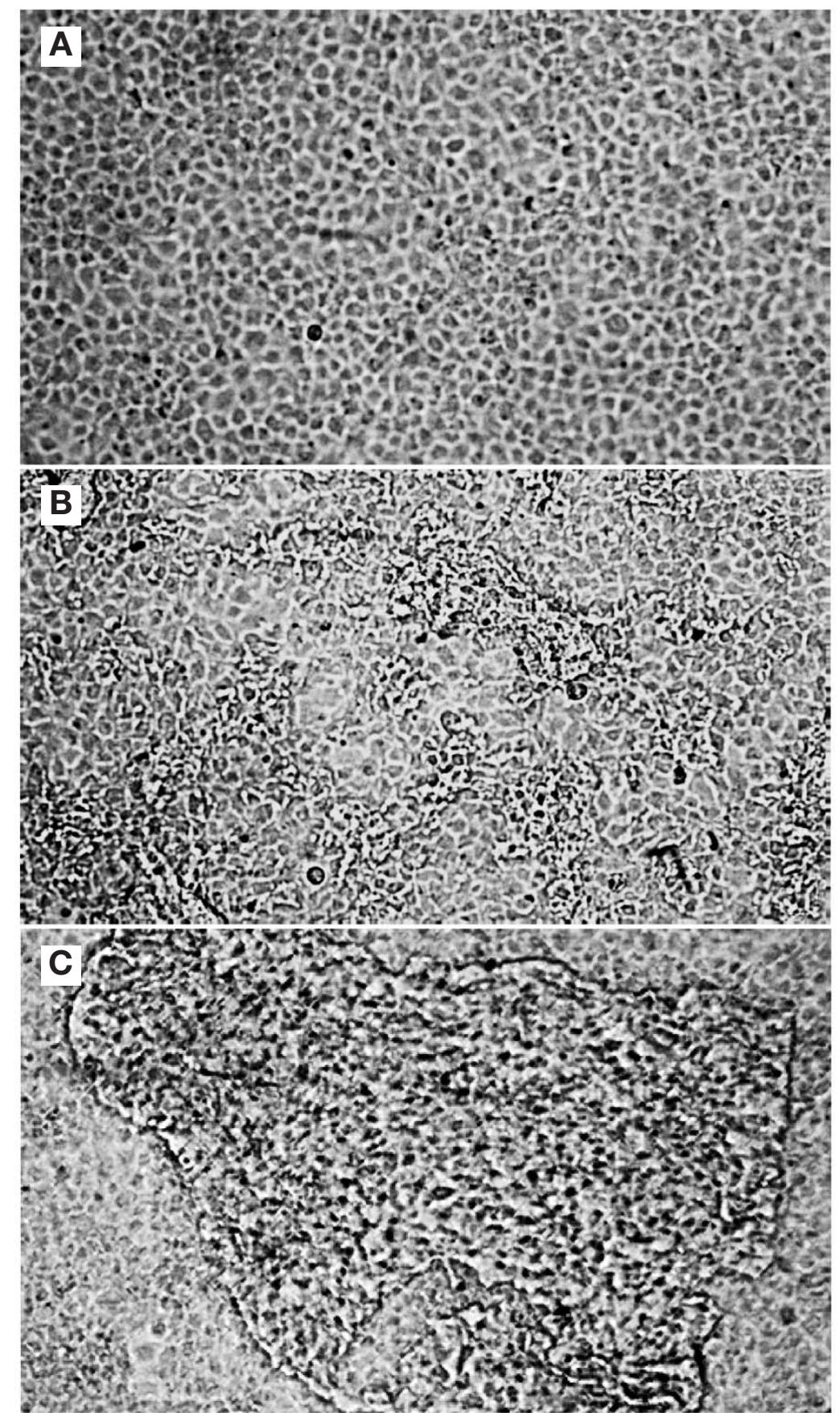

Fig. 1. Lymphocystis virus (LV)-induced cytopathogenic effect in infected GCO (grass carp ovary) cells $(\times 160)$. (A) Uninfected GCO control cells; (B) infected cells at $1 \mathrm{~d}$ post-inoculation; (C) infected cells at $3 \mathrm{~d}$ post-inoculation 

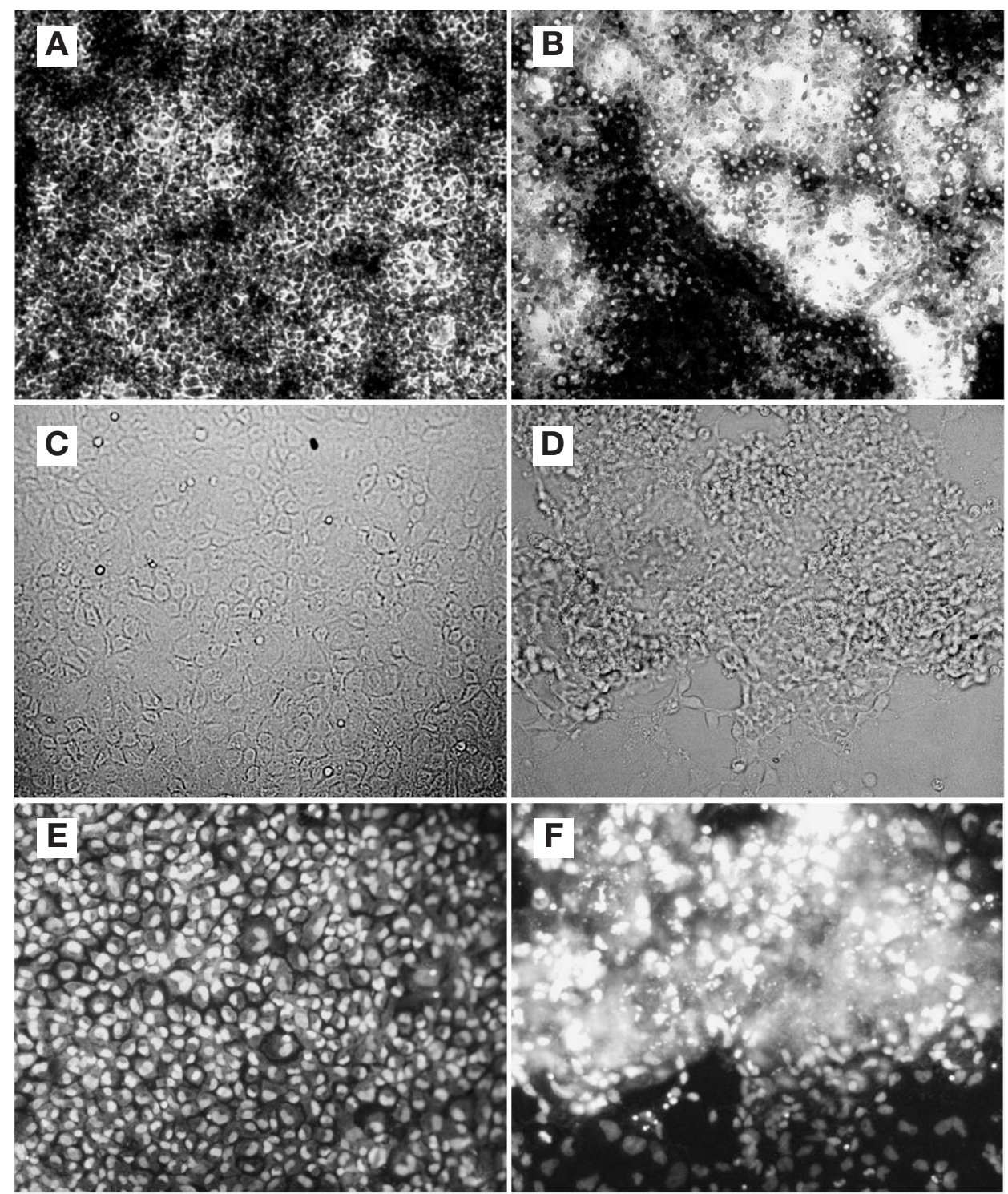

Fig. 2. Light microscopic characteristics of cytopathogenic effects in LV-infected GCO cells. Left: uninfected control cells; right: infected cells showing cytopathic effects. $(A, B)$ Staining with Giemsa $(\times 80)$; $(C-F)$ staining with Hoechst 33258; $(C, D)$ observed by ordinary light microscopy and $(\mathrm{E}, \mathrm{F})$ by fluorescence microscopy $(\times 150)$

Fluorescence microscopic observation revealed morphological characteristics of CPE in the infected cells. Normal GCO cell nuclei stained uniformly with Hoechst 33258, and the contour between a green-blue nucleus and cytoplasm was clear in control cells (Fig. 2C,E). In infected GCO cells, the green-blue fluorescence was diffused in the cytopathogenic patch. Affected cells became either hypertrophied or broken. Some marked changes in nucleus morphology, including fragmentation into lobular structures and nuclear lysis, were observed (Fig. 2D,F). Much of the lysed nuclear debris was present in the cytopathogenic patch.

\section{Electron microscopic observation of propagated viruses}

In the infected GCO cells that had produced CPE, the LV propagated rapidly. High concentrations of virus particles were visible in the cytoplasm and nucleus (Fig. 3A). A viromatrix composed of electrondense fiber-like materials was also observed in the cytoplasm. The viromatrix contained various virus particles at different stages of development, including empty capsids and matured nucleocapsids (Fig. 3A); it was similar to that observed in another iridovirus, RGV (Rana grylio virus) (Zhang et al. 1999, 2001), and may also be the central area for the LV assembly. Abundant 

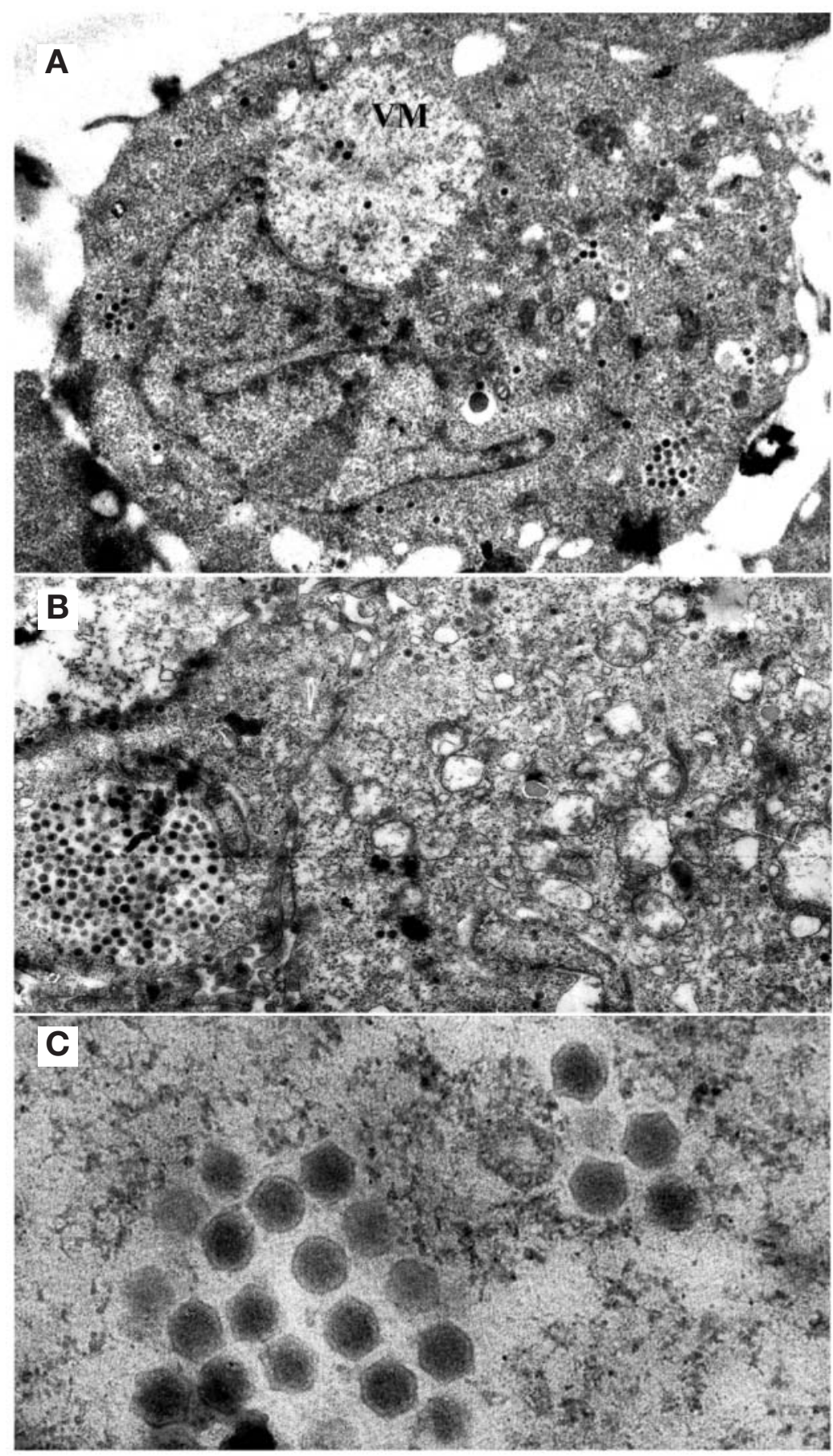

Fig. 3. Electron micrographs of infected cell and propagated virus particles. (A) Typical LV-infected cell containing 1 viromatrix $(\mathrm{VM})$ and large number of propagated virus particles $(\times 4600)$; (B) aggregation of propagated virus particles $(\times 8500)$; $(\mathrm{C})$ enlarged micrograph of propagated virus particles $(\times 42600)$

mature virus particles aggregated in the cytoplasm of some cells, but none of the crystalline arrays found in other iridoviruses (Zhang et al. 1999) were observed (Fig. 3B). Matured icosahedral virus particles in the cytoplasm were relatively uniform in size, with a diameter of approximately $170 \mathrm{~nm}$ (Fig. 3C).

\section{Ultrastructure analysis of infected cells}

Distinct changes, such as chromatin compaction and margination, vesicle formation, cell surface convolution and cell fusion, were revealed by ultrastructure analysis of the infected GCO cells (Fig. 4A). Most of the 


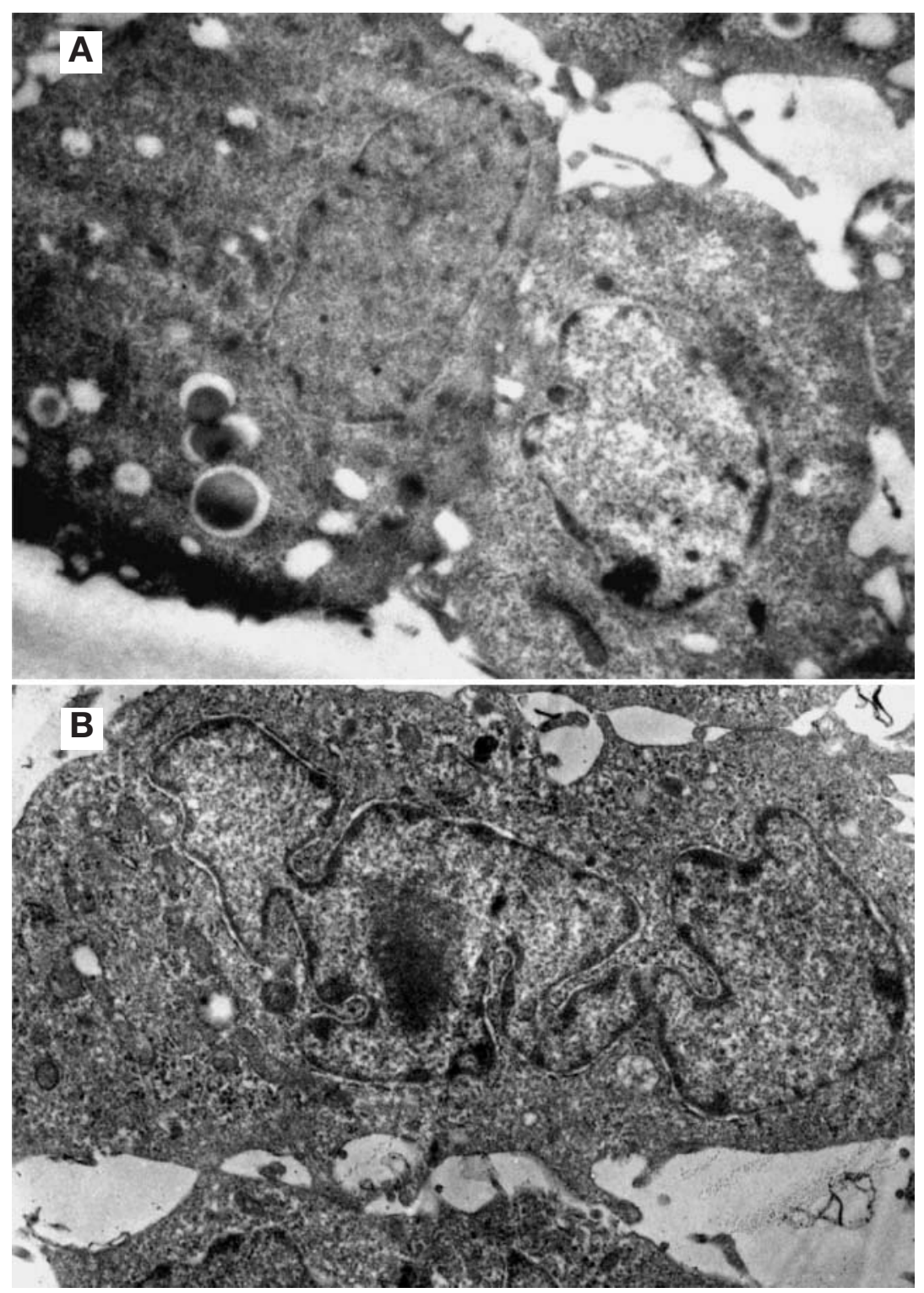

Fig. 4. Cellular changes observed by electron microscopy in infected GCO cells. (A) Chromatin compaction and margination, vesicle formation, cell-surface convolution and cell fusion in the 2 cells $(\times 4300)$; (B) nuclear fragmentation and characteristic 'blebs' visible in cell $(\times 12000)$

nuclei were of eccentric size or shape, and gave rise to fragmentation and characteristic 'blebs' (Fig. 4B).

\section{DISCUSSION}

In the current study, 13 fish cell lines were used to examine virus susceptibility, and 2 grass carp cell lines, GCO and GCK, were determined to be susceptible to the LV isolated from cultured flounder Paralichthys olivaceus in China. In addition to the susceptibility of freshwater fish cell lines to LV, cytopathic characteris- tics induced by the LV in GCO cells were demonstrated by Giemsa staining and fluorescence microscopic observation using Hoechst 33258 staining. Furthermore, a large number of propagated virus particles were detected in the infected GCO cells by electron microscopy. These results indicate that the LV replicated well in the grass carp cell line, and can therefore be passed in GCO cells.

Since the detection of LV by direct electron microscopy in 1962 (Walker 1962), many attempts have been made to propagate LV in vitro, but no efficient propagation of the virus in cultured cells has been docu- 
mented to date: 3 fish cell lines - the bluegill fry cell line BF2 (Wolf et al. 1966, Walker \& Hill 1980), the gilthead seabream (Sparus aurata L.) fin cell line SAF-1 (Perez-Prieto et al. 1999), and the Asian seabass fry cell line SF (Chang et al. 2001) - were used to evaluate their susceptibility to LV, and in all cases CPE was recorded after inoculation, but a complete replication of the virus was not achieved. The present study has demonstrated the susceptibility of 2 grass carp cell lines to LV, and has also demonstrated the propagation of virus particles in the infected GCO cells under the electron microscope.

Iridoviruses of the genus Ranavirus are associated with high mortality in lower vertebrate animals (Zhang et al. 2001, Chinchar 2002), and we observed some similar characteristics in the LV virus in the present study (e.g. an aggregated distribution of mature LV particles in the cytoplasm; Fig. 3B); however, the replication efficiency of the LV in the culture cells was much lower. For example, iridovirus RGV infectivity has a TCID $5010^{6}$ at $25^{\circ} \mathrm{C}$, whereas maximum LV infectivity is achieved with only $\operatorname{TCID}_{50} 10^{3}$. This may be related to the virus properties and pathogenetic mechanism. Lymphocystis disease is characterized by the development of nodules or tumor-like clusters on the skin and fins of infected fishes that are provoked by abnormal enlargement of cells (Wolf 1988). Cytopathological characteristics induced by the LV in culture cells were also obviously different from those described previously for other aquatic animal viruses (Zhang et al. 1999, 2000, 2001). Several distinct cellular changes, such as chromatin compaction and margination, vesicle formation, cell-surface convolution, nuclear fragmentation and the occurrence of characteristic 'blebs' and cell fusion, were revealed by ultrastructure analysis of the infected GCO cells. These changes, identical to the typical medial steps of apoptosis (Flint et al. 2000), indicated the presence of a possible apoptotic mechanism in LV pathogenesis. In nature, LV-infected fishes develop clusters of lymphocystis cells, and the individual cells may undergo a 50000 - to 100000 -fold increase in size (Tidona \& Darai 1999). However, although infected fishes are unsightly, the disease rarely causes death. During the cell infection process, we observed that obvious CPEs first appeared in GCO cell monolayers at $1 \mathrm{~d}$ post-inoculation, and had extended to about $75 \%$ of the cell monolayer at $3 \mathrm{~d}$ post-inoculation (Fig. 1). However, no further CPEs were observed after $4 \mathrm{~d}$ post-inoculation. In combination with these cellular changes, we believe that LV infection initiates rapid cell death, and thus prevents further infection and virus propagation. There were large numbers of LV particles present in the medium after $4 \mathrm{~d}$ of infection, and neither infected nor non-infected cells were able to survive. This could be the reason why no further CPE extension was observed after $4 \mathrm{~d}$ post-inoculation.

The lymphocystis virus is distributed worldwide, and the resultant lymphocystis disease has been reported to occur in over 100 different fish species in marine and freshwaters. According to a recent report (Grinwis et al. 2001), a series of experiments have been set up to examine the effects of pollution on marine and estuarine fish health, since the European flounder has shown a relatively high prevalence of lymphocystis disease in Dutch coastal and estuarine waters. The major impact of LV on infected fishes is the production of unsightly tumor-like external lesions that appear as white or grey nodules on fins and skin, and result in significant economic losses. Therefore, studies on the molecular mechanism underlying LV infection, replication and pathogenesis are important.

In summary, this study has provided a detailed report of LV infection and propagation in a freshwater fish cell line, and clear electron microscopy evidence of the propagated virus in infected cells. A possible process by which the CPE is controlled has been suggested. These data will be useful in understanding the interaction between the LV and host cells and the mechanism underlying LV infection and propagation.

Acknowledgements. This study was supported by grants from the National 863 High Technology Research program (2001AA626030), the National Natural Science Foundation of China (30170726), the Project of Chinese Academy of Sciences (STZ-00-13, KSCX2-SW-302) and the Frontier Science Projects Program of the Institute of Hydrobiology, Chinese Academy of Sciences (220301).

\section{LITERATURE CITED}

Ahne W (1978) Isolation and characterization of infectious pancreatic necrosis virus from pike (Esox lucius). Arch Virol 58:65-69

Ahne W (1985) Use of fish cell cultures for toxicity determination in order to reduce and replace the fish tests. Zentralbl Bakteriol Mikrobiol Hyg [B] 180:480-504

Berthiaume L, Alain R, Robin J (1984) Morphology and ultrastructure of lymphocystis disease virus a fish iridovirus, grown in tissue culture. Virology 135:10-19

Bowser PR, Plumb JA (1980) Growth rates of a new cell line from channel catfish ovary and channel catfish virus replication at different temperatures. Can J Fish Aquat Sci 37: 871-873

Chang SF, Ngoh GH, Kuch LFS, Qin QW, Chen CL, Lam TJ, Sin YM (2001) Development of a tropical marine fish cell line from Asian seabass (Lates calcarifer) for virus isolation. Aquaculture 192:133-145

Chen YX, Xie J (1995) The establishment of a cell line from the eel (Anguilla japonica). Trans Res Fish Dis 2:9-14

Chinchar VG (2002) Ranaviruses (family Iridovirudae): emerging cold-blooded killers. Arch Virol 147:447-470

Darai G, Anders K, Koch HG, Delius H, Gelderblom H, Samalecos C, Flugel RM (1983) Analysis of the genome of fish 
lymphocystis disease virus isolated directly from epidermal tumours of Pleuronectes. Virology 126:466-479

Fijan N, Sulimanovic D, Berzotti M, Nuzinic D, Zwillenberg LO, Chilmonezyk S, Vautherot JF, de Kinkelin P (1983) Some properties of the Epithelioma papulosum cyprini (EPC) cell line from carp Cyprinus carpio. Ann Virol 134E: 207-220

Flint SJ, Enquist LW, Krug RM, Racaniello VR, Skalka AM (2000) Principles of virology: molecular biology, pathogenesis, and control. American Society of Microbiology Press, Washington, DC

Flugel RM, Darai G, Gelderblom H (1982) Viral proteins and adenosine triphosphate phosphohydrotase activity of fish lymphocystis disease virus. Virology 122:48-55

Gravell M, Malsberger RG (1965) A permanent cell line from the fathead minnow (Pimephales promelas). Ann NY Acad Sci 126:555-565

Grinwis GC, van den Brandhof EJ, Engelsma MY, Kuiper RV, Vaal MA, Vethaak AD, Wester PW, Vos JG (2001) Toxicity of PCB-126 in European flounder (Platichthys flesus) with emphasis on histopathology and cytochrome P4501A induction in several organ systems. Arch Toxicol 75:80-87

Heppell J, Berthiaume L (1992) Ultrastructure of lymphocystis disease virus (LDV) as compared to frog virus3 (FV3) and chilo iridescent virus (CIV): effects of enzymatic digestions and detergent degradations. Arch Virol 125:215-226

Li Z, Zhang QY (2000) Culturing of the early embryos of the silver carp Hypophchalmichtheys Militrix. Reservoir Fish 20:11

Perez-Prieto SI, Rodriguez-Saint-Jean S, Garcia-Rosaso E, Castro D, Alvarez MC, Borrego JJ (1999) Virus susceptibility of the fish cell line SAF-1 derived from gill-head seabream. Dis Aquat Org 35:149-153

Samalecos CP (1986) Analysis of the structure of fish lymphocystis disease virions from skin tumors of Pleuronectes. Arch Virol 91:1-10

Schnitzler P, Darai G (1993) Identification of the gene encoding the major capsid protein from fish lymphocystis disease virus. J Gen Virol 74:2143-2150

Sun X, Qu L, Zhang J (2000) Pathogenicity and immunogenicity of lymphocystis virus of Japanese flounder (Para-

Editorial responsibility: Jo-Ann Leong,

Kaneohe, Hawaii, USA lichthys olivaceus). High Technol Lett 9:19-21

Tidona CA, Darai G (1997) The complete DNA sequence of lymphocystis disease virus. Virology 230:207-216

Tidona CA, Daral G (1999) Lymphocystis disease virus (Iridoviridae). In: Granoff A, Wevster RG (eds) Encyclopedia virology. Academic Press, New York, p 908-911

Walker R (1962) Fine structure of a virus tumor of fish. Virology 18:503-505

Walker DP, Hill BJ (1980) Studies on the culture assay of infectivity and some in vitro properties of lymphocystis virus. J Gen Virol 51:385-395

Wolf K (1988) Fish virus and fish viral diseases. Cornell University Press, Ithaca, NY

Wolf K, Gravell M, Malsberger RG (1966) Lymphocystis virus: isolation and propagation in centrarchid fish cell lines. Science 151:1004-1005

Xu HT, Piao CA, Jiang ZL, Wang WX (2000) Study on the causative agent of lymphocystic disease in cultured flounder, Paralichthys olivaceus, in Mainland China. Chin J Virol 16:223-226

Zhang QY (2002) A review of viral diseases of aquatic animals in China. Acta Hydrobiol Sin 26:89-101

Zhang QY, Li ZQ, Jiang YL, Liang SC, Gui JF (1996) Preliminary studies on virus isolation and cell infection from disease frog Rana grylio. Acta Hydrobiol Sin 20:390-392 (in Chinese with English abstract)

Zhang QY, Li ZQ, Gui JF (1999) Studies on morphogenesis and cellular interactions of Rana grylio virus in an infected fish cell line. Aquaculture 175:185-197

Zhang QY, Li ZQ, Gui JF (2000) Isolation of a lethal rhabdovirus from the cultured Chinese sucker Myхосурrinus asiaticus. Dis Aquat Org 42:1-9

Zhang QY, Xiao F, Li ZQ, Gui JF, Mao JH, Chinchar VG (2001) Characterization of an iridovirus from the cultured pig frog (Rana grylio) with lethal syndrome. Dis Aquat Org 48:27-36

Zuo WG, Qian HX, Xu YF (1986) Establish and characterization of grass carp (Ctenopharyngodon idellus) kidney (CIK) cell line. J Fish China 10:11-17

Zwillenberg LD, Wolf K (1968) Ultrastructure of lymphocystis virus. J Virol 2:393-399

Submitted: September 8, 2002; Accepted: April 24, 2003

Proofs received from author(s): September 29, 2003 